\section{Unusual case of a stage I thymoma of the posterior mediastinum: endoscopic ultrasound-guided fine needle aspiration alone clinches the diagnosis}
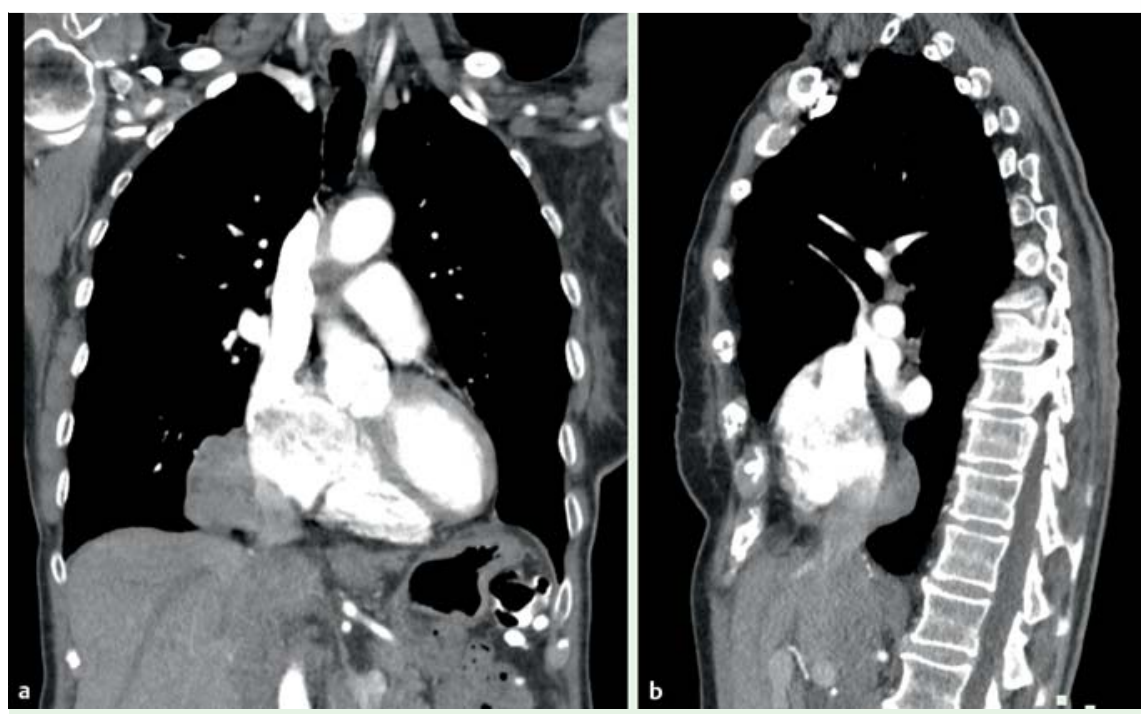

Fig. 1 Computed tomography (CT) scan of the chest showing a solid mass measuring $6.1 \times 3.5 \times$ $4.6 \mathrm{~cm}$ that was abutting the right atrium and inferior vena cava: $\mathbf{a}$ in coronal view; $\mathbf{b}$ in sagittal view.

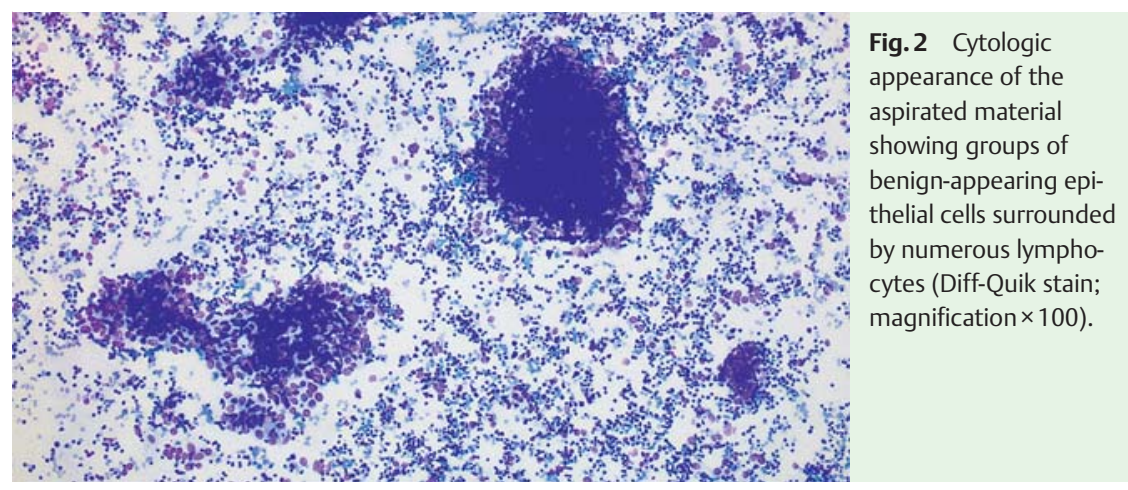

Whilst recurrent mediastinal thymoma is not unusual, particularly if the neoplasm was malignant and invasive, there have been few reports confirming tissue acquisition endoscopically, and these have required either core biopsy needles or "special" maneuvers $[1,2]$. We present a rare case of recurrent stage I thymoma arising from the posterior mediastinum that was diagnosed on endoscopic ultrasoundguided fine needle aspiration (EUS-FNA) alone, substantiating the role of EUS-FNA in the diagnosis of mediastinal lesions.

A 73-year-old woman with a history of myasthenia gravis and thymoma who had undergone thymectomy 32 years previously presented with an incidental finding on a computed tomography (CT) scan

of a $6.1-\mathrm{cm}$ lobulated mass along the right heart border ( $\bullet$ Fig. 1). EUS using a linear echoendoscope (UCT180; Olympus America, Center Valley, Pennsylvania, USA) identified a hypoechoic mass with ill-defined borders ( Video 1 ). A transesophageal FNA, without suction, using a 22G needle (Expect; Boston Scientific, Natick, Massachusetts, USA) yielded diagnostic

\section{Video 1}

Examination with a linear echoendoscope showing a large posterior mediastinal mass and a diagnostic tissue aspirate being obtained without suction using a $22 \mathrm{G}$ fine needle aspiration (FNA) needle. material on the first pass. Onsite cytology showed mixed neoplastic epithelial cells and reactive lymphocytes, consistent with a stage I thymoma ( Fig.2). Two additional passes were performed for preparation of a cell block, which later confirmed the onsite diagnosis.

The tumor is believed to have arisen from residual thymic tissue. This case is unique because: thymomas of the posterior mediastinum are uncommon; noninvasive thymomas rarely recur, particularly so late after resection; and diagnosis was obtained on EUS-FNA alone [3,4]. The patient's predicted long-term survival is excellent and radiotherapy was not recommended [5].

EUS-FNA is a novel modality in diagnosing posterior mediastinal lesions, which may prove to be as accurate as traditional diagnostic modalities [6-8]. Unusual and unexpected lesions often require additional tissue for ancillary testing, which can be provided by EUS, thereby avoiding the need for methods such as CT-guided biopsy, which can degrade sample quality and interpretation [9]. This case exemplifies how EUS-FNA using a standard FNA needle is a highly useful, minimally invasive technique with multiple applications.

\section{Endoscopy_UCTN_Code_TTT_1AS_2AC}

Competing interests: Drs. S. Hébert-Magee and S.Varadarajulu are consultants for Boston Scientific. No financial relationships relevant to this publication are disclosed.

\section{Bronte A. Holt, Shyam Varadarajulu, Konrad Krall, Shantel Hébert-Magee}

Center for Interventional Endoscopy, Florida Hospital, Orlando, Florida, USA

\section{References}

1 Larghi A, Rodriguez-Wulff E, Dye CE et al. Recurrent malignant thymoma diagnosed by EUS-guided Trucut biopsy. Gastrointest Endosc 2006; 63: 859-860

2 Larghi A, Noffsinger A, Waxman I et al. EUSguided fine needle tissue acquisition by using high negative pressure suction for the evaluation of solid masses: a pilot study. Gastrointest Endosc 2005; 62: 768-774

3 Awad WI, Symmans PJ, Dussek JE. Recurrence of stage I thymoma 32 years after total excision. Ann Thorac Surg 1998; 66: 2106 -2108

4 Orki A, Patlakoglu MS, Kutlu CA et al. Malignant invasive thymoma in the posterior mediastinum. Ann Thorac Surg 2009; 87: $1274-1275$

5 Wu KL, Mao JF, Jiang GL et al. Prognostic predictors and long-term outcome of post- 
operative irradiation in thymoma: a study of 241 patients. Cancer Invest 2009; 27: 1008 1015

6 Eloubeidi MA. Endoscopic ultrasound-guided fine-needle aspiration in the staging and diagnosis of patients with lung cancer. Sem Thorac Cardiovasc Surg 2007; 19: 206-211

7 Cerfolio RJ, Bryant AS, Eloubeidi MA. Routine mediastinoscopy and esophageal ultrasound fine-needle aspiration in patients with non-small cell lung cancer who are clinically N2 negative: a prospective study. Chest 2006; 130: 1791 -1795
8 Ahrar K, Wallage M, Javadi S et al. Mediastinal, hilar, and pleural image-guided biopsy: Current practice and techniques. Sem Resp Crit Care Med 2008; 29: 350-360

9 Varadarajulu S, Hasan MK, Hawes $R H$ et al. Endoscopic ultrasound-guided tissue acquisition. Dig Endosc 2014; 26: 62 -69

Bibliography

DOI http://dx.doi.org/

10.1055/s-0034-1365781

Endoscopy 2014; 46: E577-E578

(c) Georg Thieme Verlag KG

Stuttgart . New York

ISSN 0013-726X
Corresponding author

\section{Shantel Hébert-Magee, MD}

Center for Interventional Endoscopy

Florida Hospital

601 E. Rollins St.

Orlando

FL 32801

USA

Fax: +1-407-303-2585

Shantel.Hebert-Magee.MD@flhosp.org 